\title{
Formulasi Konsorsium Bakteri Endofit untuk Menekan Infeksi Nematoda Puru Akar Meloidogyne incognita pada Tomat
}

\author{
Ankardiansyah Pandu Pradana ${ }^{1}$, Abdul Munif ${ }^{2}$, Supramana ${ }^{2}$ \\ ${ }^{1}$ Program Studi Proteksi Tanaman, Fakultas Pertanian, Universitas Jember. Email: pandu@unej.ac.id \\ ${ }^{2}$ Departemen Proteksi Tanaman, Fakultas Pertanian, Institut Pertanian Bogor
}

Received: $15-09-2020$

Accepted:16-10-2020

Available online:01-11-2020

\begin{abstract}
The root-knot nematodes (Meloidogyne incognita) infection can cause a significant yield loss in tomato plants. One of the environmentally friendly efforts to control this nematode is through the application of endophytic bacteria. The application of endophytic bacteria in a consortium was reported to be more effective than the application using a single isolate. This study aims to test the effectiveness of the endophytic bacteria consortium formula in suppressing $M$. incognita infection in tomato plants. The research stages were selecting the consortium of endophytic bacteria as a growth promoter for tomato plants infected with $M$. incognita. The best performing consortium was formulated using $100 \mathrm{~g}$ of grass compost $+100 \mathrm{~g}$ vermicompost $+10 \mathrm{ml}$ molasses $+1 \mathrm{~g}$ peptone and $50 \mathrm{ml}$ distilled water. The test of bacterial cell viability in the endophytic formula was carried out for 20 weeks. The formula made was tested for its performance as a biocontrol agent against $\mathrm{M}$. incognita in tomato plants. The results showed that three consortia gave the best results as growth promoters of $M$. incognita infected tomatoes, namely TmtN5, TmtN2, and GsgN2. The three of them survived the formula with log CFU at week 20 of 6.07 (TmtN5), 5.56 (TmtN2), and 6.11 (GsgN2). This formula can suppress the nematode population on tomato plants' roots and suppress the number of root knots in tomato plants. This study provides information that there are three consortia of endophytic bacteria (TmtN5, TmtN2, and GsgN2), which have the potential to become biological control agents for root-purulent nematodes.
\end{abstract}

Keywords: biocontrol, compost, formula, suppression, viability

\begin{abstract}
ABSTRAK
Infeksi nematoda puru akar Meloidogyne incognita menyebabkan penurunan hasil panen tomat yang cukup signifikan. Upaya pengendalian ramah lingkungan yang dapat dilakukan salah satunya melalui aplikasi agens biokontrol bakteri endofit. Aplikasi bakteri endofit dalam bentuk konsorsium dilaporkan lebih efektif dibandingkan dengan aplikasi menggunakan isolat tunggal. Penelitian ini bertujuan untuk menguji efektifitas formula konsorsium bakteri endofit dalam menekan infeksi $M$. incognita pada tanaman tomat. Tahapan penelitian yang dilakukan adalah seleksi konsorsium bakteri endofit sebagai pemacu pertumbuhan tanaman tomat terinfeksi $M$. incognita. Konsorsium dengan performa terbaik diformulasi menggunakan $100 \mathrm{~g}$ kompos rumput $+100 \mathrm{~g}$ kascing $+10 \mathrm{ml}$ molase $+1 \mathrm{~g}$ pepton dan $50 \mathrm{ml}$ akuades. Uji viabilitas sel bakteri di dalam formula endofit dilakukan selama 20 minggu. Formula yang telah dibuat diuji performanya sebagai agens biokontrol terhadap $M$. incognita pada tanaman tomat. Hasil penelitian menunjukkan terdapat 3 konsorsium yang memberikan hasil terbaik sebagai pemacu pertumbuhan tanaman tomat terinfeksi M. incognita, yaitu TmtN5, TmtN2, dan GsgN2. Ketiganya dapat bertahan pada formula dengan log CFU pada minggu ke 20 sebesar 6,07 (TmtN5), 5,56
\end{abstract}




\section{TECHNO: Vol. 09 (02) Oktober 2020}

(TmtN2), dan 6,11 (GsgN2). Formula tersebut mampu menekan populasi nematoda pada perakaran tanaman tomat dan menekan umlah puru akar pada tanaman tomat. Penelitian ini memberikan informasi terdapat 3 konsorsium bakteri endofit (TmtN5, TmtN2, dan GsgN2) yang berpotensi menjadi agens pengendali hayati nematoda puru akar.

Kata Kunci: biokontrol, formula, kompos, penekanan, viabilitas

\section{PENDAHULUAN}

Nematoda puru akar Meloidogyne incognita dikenal sebagai salah satu patogen kosmopolit yang dapat menginfeksi tanaman hortikultura, pangan, industri, maupun perkebunan. M. incognita dapat menyebabkan kehilangan hasil yang cukup tinggi, bahkan gagal panen pada beberapa komoditas (Ntalli dan Caboni, 2017). Pada tanaman tomat, M. incognita dapat menyebabkan kehilangan hasil sampai dengan $30 \%$. Namun demikian, bila infeksi nematoda puru akar diikuti oleh infeksi cendawan atau bakteri patogen, kehilangan hasil akan semakin tinggi (Viljoen et al., 2019). Kumar et al. (2017) melaporkan sinergisme Fusarium oxysporum dan M. incognita dapat menyebabkan kehilangan hasil sampai dengan $70 \%$ pada tomat. Selanjutnya, pada laporan terpisah, Furusawa et al. (2019) juga melaporkan sinergisme Ralstonia solanacearum dan M. incognita dapat menyebabkan kehilangan hasil sampai dengan $85 \%$, bahkan menyebabkan tanaman mati.

Berbagai upaya telah dilakukan untuk menekan infeksi nematoda pada tanaman tomat. Namun demikian, sampai saat ini infeksi $M$. incognita masih menjadi permasalahan yang belum dapat diselesaikan sepenuhnya. Relung hidup nematoda puru akar yang unik menyebabkan nematoda ini cukup sulit dikendalikan (Xiang et al., 2017). Pada fase Juvenil-2, nematoda puru akar dapat hidup di daerah perakaran tanaman, dan setelah menemukan inangnya, ia akan menginfeksi inangnya dan hidup di dalam jaringan akar (Muhae-Ud-Din et al., 2018). Berdasarkan cara hidupnya tersebut, nematoda ini dikenal sebagai nematoda parasit menetap. Posisi nematoda puru akar yang dapat berada di daerah perakaran tanaman dan di dalam jaringan akar menyebabkan upaya pengendalian secara konvensional kurang begitu efektif (Khanna et al., 2019).

Solusi efektif dan ramah lingkungan untuk mengendalikan nematoda puru akar adalah pengendalian secara biologi menggunakan bakteri endofit. Bakteri endofit hidup di dalam jaringan akar tanaman, menempati relung hidup yang sama dengan nematoda puru akar (Eljounaidi et al., 2016). Aplikasi bakteri endofit dapat menekan populasi M. incognita secara langsung maupun tidak langsung. Secara langsung bakteri endofit dilaporkan dapat memproduksi metabolit sekunder seperti enzim kitinase, enzim protease, dan HCN yang bersifat nematisidal (Anjum et al., 2019). Selanjutnya, secara tidak langsung bakteri endofit dapat menginduksi ketahanan tanaman inang terhadap infeksi patogen seperti $M$. incognita $(\mathrm{Hu}$ et al., 2017).

Pada penelitian sebelumnya, tim peneliti telah menemukan 80 konsorsium bakteri endofit dari akar tanaman bambu (Bambusa bambos), mint (Coleus amboinicus), bit merah (Beta vulgaris), gingseng (Talinum triangulare), pecah beling ungu (Strobilanthes crispus), pacar air (Impatiens balsamina), tomat (Lycopersicum esculentum), sereh (Cymbopogon nardus), padi (Oryza sativa), tithonia (Tithonia diversifolia), kumis kucing (Orthosiphon aristatus), binahong (Anredera cordifolia), jinten (Nigella sativa), temulawak (Curcuma xanthorrhiza), garut (Maranta arundinacea), 
dan cabai rawit (Capsicum frutescens). Sebanyak 17 konsorsium bakteri endofit diketahui aman bagi tumbuhan dan mamalia, serta dapat memproduksi enzim kitinase, enzim protease, $\mathrm{HCN}$, dan mampu melarutkan fosfat (P) serta menambat nitrogen (N) (Pradana et al., 2016). Aplikasi agens biokontrol dalam bentuk konsorsium dilaporkan lebih efektif dibandingkan dengan penggunaan agens biokontrol secara tunggal (Ashraf et al., 2018). Pada penelitian sebelumnya, Munif dan Giyanto (2015) melaporkan konsorsium bakteri endofit efektif menekan kerusakan akar akibat infeksi Pratylenchus coffeae pada tanaman kopi. Penekanan kerusakan akar kopi oleh konsorsium bakteri endofit dilaporkan lebih baik dibandingkan dengan penekanan oleh isolat tunggal. Selanjutnya, pada laporan terpisah, Varkey et al. (2018) melaporkan konsorsium bakteri endofit efektif menekan tingkat infeksi M. incognita pada tanaman tomat.

Pada umumnya, agens biokontrol seperti bakteri endofit akan lebih mudah diterima oleh masyarakat dalam bentuk formula. Formula konsorsium bakteri endofit dapat dibuat dalam bentuk padat dan cair. Formulasi agens biokontrol bertujuan untuk menjaga viabilitas sel bakteri selama masa penyimpanan dan menghindari terjadinya perubahan sifat (Basheer et al., 2019). Penelitian ini bertujuan untuk menguji efektifitas formula konsorsium bakteri endofit dalam menekan infeksi $M$. incognita pada tanaman tomat.

\section{METODE PENELITIAN}

\section{Sumber Konsorsium Bakteri Endofit}

Sebanyak 17 konsorsium bakteri endofit berasal dari penelitian sebelumnya (Pradana et al., 2016). Konsorsium bakteri endofit yang digunakan adalah PcrN5, PcrT2, MntT5, BitT2, GsgN5, GsgN2, PbuT2, JtnT2, GsgT2, CbiKB, PbuN5, BitN5, TmtN2, TmtN5, PdiT2, PtmN2, dan PdiN2.

\section{Sumber Inokulum Meloidogyne incognita}

Inokulum M. incognita diperoleh dari Laboratorium Nematologi Tumbuhan - Institut Pertanian Bogor. Perbanyakan M. incognita dilakukan dengan menginokulasi tanaman tomat yang ditanam pada tanah steril. Setelah enam puluh hari, paket telur yang terbentuk kemudian dipanen dan diinokulasikan ulang ke tanaman tomat pada tanah steril lainnya. Kegiatan ini dilakukan secara terus menerus untuk memperoleh telur $M$. incognita dalam jumlah besar dan murni (Chawla et al., 2006).

\section{Seleksi Konsorsium Bakteri Endofit Sebagai Pemacu Pertumbuhan Tanaman Tomat Terinfeksi M. incognita}

Tanaman tomat varietas Tantyna F1 disemai pada tanah yang telah disterilkan. Empat puluh hari setelah semai, dilakukan pemindahan tanam. Tomat ditumbuhkan pada media tanah : kompos : pasir $(1: 1: 1, \mathrm{w} / \mathrm{w})$ yang telah disterilisasi menggunakan autoklaf. Penanaman dilakukan di rumah kaca menggunakan plot pastik dengan diameter $15 \mathrm{~cm}$ dan tinggi $20 \mathrm{~cm}$. Percobaan dilakukan mengikuti pola rancangan acak kelompok dengan 5 ulangan, 18 perlakuan, dan setiap perlakuan terdiri atas 3 tanaman uji yang ditanam pada pot yang berbeda.

Tiga puluh hari setelah pindah tanam, tanaman tomat diinokulasi dengan 300 Juvenil-2 (J2) M. incognita per tanaman. Aplikasi konsorsium bakteri endofit dilakukan pada 7 hari, 14 hari, 21 hari, dan 35 hari setelah inokulasi M. incognita ke tanaman tomat. Konsorsium bakteri diperoleh dengan mengkulturkan setiap konsorsium pada media cair Tryptic Soy Broth (TSB) (HiMedia, 


\section{TECHNO: Vol. 09 (02) Oktober 2020}

India) 100\% selama 48 jam. Jumlah konsorsium bakteri endofit yang diaplikasikan adalah 100 $\mathrm{ml}$ dengan kerapatan $10^{8} \mathrm{cfu} \mathrm{ml}^{-1}$ per tanaman. Sebagai kontrol, tanaman tomat ditanam tanpa perlakuan menggunakan konsorsium bakteri endofit.

Pengamatan dilakukan 40 hari setelah inokulasi M. incognita, yang merupakan tahap preliminary infection. Tahap preliminary infection dapat menggambarkan dengan baik tingkat efektifitas agens biokontrol terhadap infeksi nematoda. Peubah pengamatan yang diamati meliputi berat segar tanaman $(\mathrm{g})$, berat kering tanaman $(\mathrm{g})$, tinggi tanaman $(\mathrm{cm})$, jumlah daun, dan panjang akar (cm) (Munif et al., 2013).

\section{Formulasi Konsorsium Bakteri Endofit Pada Kompos}

Konsorsium bakteri endofit diformulasi menggunakan bahan pembawa utama kompos rumput dan kompos kascing. Kompos rumput diperoleh dari Balai Penelitian Tanaman Rempah dan Obat (Balittro) Bogor, dan kompos kascing diperoleh dari kebun Pusat Penelitian Biofarmaka Institut Pertanian Bogor. Konsorsium yang diformulasi adalah 3 konsorsium yang menunjukkan formula terbaik pada pengujian sebelumnya. Kombinasi formula yang digunakan pada penelitian ini adalah sebagai berikut:

1. Konsorsium terbaik $1+100 \mathrm{~g}$ kompos rumput $+100 \mathrm{~g}$ kascing $+10 \mathrm{ml}$ molase $+1 \mathrm{~g}$ pepton $+50 \mathrm{ml}$ akuades;

2. Konsorsium terbaik $1+100 \mathrm{~g}$ kompos rumput $+100 \mathrm{~g}$ kascing $+10 \mathrm{ml}$ molase $+1 \mathrm{~g}$ pepton $+50 \mathrm{ml}$ akuades;

3. Konsorsium terbaik $1+100 \mathrm{~g}$ kompos rumput $+100 \mathrm{~g}$ kascing $+10 \mathrm{ml}$ molase $+1 \mathrm{~g}$ pepton $+50 \mathrm{ml}$ akuades.

Formulasi dilakukan dengan mencampur seluruh bahan pembawa pada plastik tahan panas, kemudian campuran tersebut disterilisasi menggunakan autoklaf. Bahan pembawa yang telah steril dan telah didinginkan selama 48 jam kemudian dicampur dengan $10 \mathrm{ml}$ suspensi konsorsium bakteri endofit dengan kerapatan $10^{8} \mathrm{cfu} \mathrm{ml}^{-1}$ (Munif dan Mutaqin, 2016).

\section{Pengujian Viabilitas Konsorsium Bakteri Endofit Dalam Formula}

Sebanyak $1 \mathrm{~g}$ formula bakteri diambil dan dilakukan pengenceran berseri sampai dengan tingkat pengenceran $10^{-4}$. Suspensi hasil pengenceran berseri diambil sebanyak $0,1 \mathrm{ml}$ dan diratakan pada media Tryptic Soy Agar (TSA) (HiMedia, India) selama 48 jam. Jumlah koloni yang tumbuh dihitung dan dikonversi menjadi log cfu ml-1 (Munif dan Mutaqin, 2016).

\section{Uji Efektifitas Formula Konsorsium Bakteri Endofit Sebagai Agens Biokontrol M. incognita Pada Tomat di Rumah Kaca}

Tanaman tomat varietas Tantyna F1 disemai pada media tanah steril. Empat puluh hari setelah semai tomat dipindah tanam pada pot dengan diameter $15 \mathrm{~cm}$ dan tinggi $20 \mathrm{~cm}$, berisi campuran tanah steril dan formula konsorsium bakteri endofit dengan perbandingan $1: 1$ $(\mathrm{w} / \mathrm{w})$. Selanjutnya, tiga puluh hari setelah pindah tanam, tanaman tomat diinokulasi dengan 300 J2 M. incognita. Percobaan dilakukan mengikuti pola rancangan acak kelompok, dengan 4 perlakuan, 5 ulangan, dan setiap ulangan terdiri atas 3 tanaman uji. Peubah pengamatan yang diamati meliputi peubah patologis dan agronomis. Peubah patologis yang diamati adalah jumlah nematoda di tanah, jumlah nematoda di dalam akar, dan jumlah puru akar. Selanjutnya, peubah agronomis yang diamati meliputi jumlah daun, tinggi tanaman $(\mathrm{cm})$, panjang akar $(\mathrm{cm})$, dan bobot segar tanaman (Cetintas et al., 2018). 
Pradana, A.P., A. Munif, Supramana. 2020. biocontrol; compost; formula; suppression;

viability

\section{Analisis Data}

Data dianalisis menggunakan analisis ragam, jika terdapat keragaman data maka dilanjutkan dengan uji lanjut Duncan Multiple Range Test (DMRT) dengan taraf kepercayaan 95\%. Program yang digunakan untuk analisis adalah DSAASTAT versi 1.021.

\section{HASIL DAN PEMBAHASAN}

Konsorsium Bakteri Endofit Sebagai Pemacu Pertumbuhan Tanaman Tomat Terinfeksi M. incognita

Secara umum pertumbuhan tomat yang diberi diberi perlakuan konsorsium bakteri endofit menunjukkan pertumbuhan yang lebih baik dibandingkan dengan tanaman kontrol. Pada peubah berat segar tanaman diketahui seluruh konsorsium bakteri endofit memberikan hasil yang berbeda nyata dengan tanaman kontrol. Namun demikian, konsorsium bakteri endofit TmtN5 memberikan pengaruh positif yang paling baik dengan rata-rata berat segar tanaman 72,05 g, diikuti oleh TmtN2 (69,96 g), PcrT2 (68,56 g), MntT5 (68,51 g), GsgT2 (68,01 g), dan konsorsium lainnya. Selanjutnya, pada peubah pengamatan berat kering tanaman, hanya konsorsium TmtN5 yang memberikan hasil berbeda nyata dengan tanaman kontrol. Konsorsium TmtN5 memberikan berat kering tanaman berat kering tanaman 8,85 g, jika dibandingkan dengan kontrol TmtN5 memiliki berat kering tanaman 15,94\% lebih tinggi.

Pada peubah pengamatan tinggi tanaman, dari seluruh konsorsium bakteri yang diuji, terdapat 5 konsorsium yang memberikan tinggi tanaman berbeda nyata jika dibandingkan dengan kontrol. Secara berurutan, kelima konsorsium yang memberikan tinggi tanaman berbeda nyata dengan tanaman kontrol adalah TmtN5 $(82.90 \mathrm{~cm})$, TmtN2 $(79 \mathrm{~cm})$, GsgN2 $(75,70 \mathrm{c}$,$) , MntT5$ $(75,70 \mathrm{~cm})$, dan PbuN5 $(74 \mathrm{~cm})$. Konsorsium lainnya memberikan tinggi tanaman yang lebih tinggi dibandingkan dengan tinggi tanaman kontrol $(65,10 \mathrm{~cm})$, namun tidak berbeda nyata pada uji selang berganda duncan pada taraf kepercayaan 95\%. Selanjutnya, pada peubah pengamatan rata-rata jumlah daun, terdapat 6 konsorsium yang memberikan hasil berbeda nyata dibandingkan dengan tanaman kontrol. Secara berurutan, konsorsium yang memberikan rata-rata jumlah daun berbeda nyata dengan tanaman kontrol adalah TmtN5 $(8,60)$, TmtN2 $(7,60), \operatorname{GsgN} 2(7,30), \operatorname{MntT} 5(7,20)$, PcrT2 $(7,00)$, dan PdiN2 $(7,00)$. Pada peubah pengamatan panjang akar, dari 17 konsorsium yang diuji, 16 diantaranya memberikan panjang akar yang berbeda nyata dengan panjang akar tanaman kontrol $(15,70 \mathrm{~cm})$. Namun demikian, tiga konsorsium paling baik pada peubah pengamatan panjang akar adalah TmtN5 $(17,57 \mathrm{~cm})$, TmtN2 $(17,26 \mathrm{~cm})$, dan BitT2 $(16,65 \mathrm{~cm})$. Lebih lanjut, data pertumbuhan tomat disajikan pada Tabel 1. 


\section{TECHNO: Vol. 09 (02) Oktober 2020}

Tabel 1. Pertumbuhan tanaman tomat terinfeksi nematoda puru akar setelah aplikasi konsorsium bakteri endofit

\begin{tabular}{llllll}
\hline $\begin{array}{l}\text { Kode } \\
\text { Konsorsium }\end{array}$ & $\begin{array}{l}\text { Berat Segar } \\
\text { Tanaman }(\mathrm{g})\end{array}$ & $\begin{array}{l}\text { Berat Kering } \\
\text { Tanaman }(\mathrm{g})\end{array}$ & $\begin{array}{l}\text { Tinggi } \\
\text { Tanaman }(\mathrm{cm})\end{array}$ & $\begin{array}{l}\text { Jumlah } \\
\text { Daun }\end{array}$ & $\begin{array}{l}\text { Panjang Akar } \\
(\mathrm{cm})\end{array}$ \\
\hline PcrN5 & $66.81 \mathrm{de}$ & $7.36 \mathrm{bc}$ & $69.75 \mathrm{~cd}$ & $6.60 \mathrm{cdef}$ & $16.10 \mathrm{de}$ \\
PcrT2 & $68.56 \mathrm{c}$ & $7.30 \mathrm{bc}$ & $71.50 \mathrm{~cd}$ & $7.00 \mathrm{bcde}$ & $16.39 \mathrm{~cd}$ \\
MntT5 & $68.51 \mathrm{c}$ & $7.15 \mathrm{c}$ & $75.70 \mathrm{bc}$ & $7.20 \mathrm{bcd}$ & $16.27 \mathrm{~cd}$ \\
BitT2 & $67.00 \mathrm{de}$ & $7.30 \mathrm{bc}$ & $69.90 \mathrm{~cd}$ & $6.60 \mathrm{cdef}$ & $16.65 \mathrm{~cd}$ \\
GsgN5 & $67.47 \mathrm{cde}$ & $6.96 \mathrm{c}$ & $68.60 \mathrm{~cd}$ & $6.40 \mathrm{def}$ & $16.53 \mathrm{~cd}$ \\
GsgN2 & $67.75 \mathrm{cde}$ & $7.57 \mathrm{bc}$ & $75.70 \mathrm{bc}$ & $7.30 \mathrm{bc}$ & $16.44 \mathrm{~cd}$ \\
PbuT2 & $67.26 \mathrm{cde}$ & $7.39 \mathrm{bc}$ & $72.30 \mathrm{~cd}$ & $6.70 \mathrm{cdef}$ & $16.51 \mathrm{~cd}$ \\
JtnT2 & $66.95 \mathrm{de}$ & $7.30 \mathrm{bc}$ & $70.40 \mathrm{~cd}$ & $6.60 \mathrm{cdef}$ & $16.63 \mathrm{~cd}$ \\
GsgT2 & $68.01 \mathrm{~cd}$ & $7.20 \mathrm{c}$ & $69.90 \mathrm{~cd}$ & $6.60 \mathrm{cdef}$ & $16.34 \mathrm{~cd}$ \\
CbiKB & $67.27 \mathrm{cde}$ & $7.56 \mathrm{bc}$ & $72.30 \mathrm{bcd}$ & $6.80 \mathrm{bcdef}$ & $16.74 \mathrm{c}$ \\
PbuN5 & $67.19 \mathrm{de}$ & $7.51 \mathrm{bc}$ & $74.00 \mathrm{bc}$ & $7.00 \mathrm{bcde}$ & $16.52 \mathrm{~cd}$ \\
BitN5 & $66.56 \mathrm{e}$ & $7.36 \mathrm{bc}$ & $69.40 \mathrm{~cd}$ & $6.30 \mathrm{ef}$ & $16.82 \mathrm{bc}$ \\
TmtN2 & $69.96 \mathrm{~b}$ & $7.95 \mathrm{~b}$ & $79.00 \mathrm{ab}$ & $7.60 \mathrm{~b}$ & $17.26 \mathrm{ab}$ \\
TmtN5 & $72.05 \mathrm{a}$ & $8.58 \mathrm{a}$ & $82.90 \mathrm{a}$ & $8.60 \mathrm{a}$ & $17.57 \mathrm{a}$ \\
PdiT2 & $67.63 \mathrm{cde}$ & $7.65 \mathrm{bc}$ & $70.90 \mathrm{~cd}$ & $6.60 \mathrm{cdef}$ & $16.39 \mathrm{~cd}$ \\
CbiN2 & $67.72 \mathrm{cde}$ & $7.31 \mathrm{bc}$ & $71.40 \mathrm{~cd}$ & $6.80 \mathrm{bcdef}$ & $16.29 \mathrm{~cd}$ \\
PdiN2 & $66.94 \mathrm{de}$ & $7.47 \mathrm{bc}$ & $71.70 \mathrm{~cd}$ & $7.00 \mathrm{bcde}$ & $16.63 \mathrm{~cd}$ \\
Kontrol & $63.78 \mathrm{f}$ & $7.40 \mathrm{bc}$ & $65.10 \mathrm{~d}$ & $6.10 \mathrm{f}$ & $15.70 \mathrm{e}$ \\
\hline A & & & &
\end{tabular}

Angka-angka pada kolom yang diikuti oleh huruf yang sama tidak berbeda nyata pada p-value 0.05 (uji selang berganda Duncan).

\section{Viabilitas Konsorsium Bakteri Endofit Dalam Formula}

Berdasarkan hasil pengujian sebelumnya, terdapat tiga konsrosium dengan performa terbaik, yaitu konsorsium TmtN5, TmtM2, dan GsgN2. Ketiga konsorsium tersebut diformulasi dan diukur viabilitasnya di dalam formula. Berdasarkan hasil pengamatan diketahui viabilitas ketiga konsorsium tersebut dalam 20 minggu pengamatan cenderung menurun. Pada minggu pertama pengamatan secara berurutan Log CFU dari konsorsium adalah 9,7 (TmtN5), 9,55 (TmtN2), dan 9,23 (GsgN2). Pada minggu ke-10 pengamatan semua konsorsium mengalami penurunan jumlah sel dalam Log CFU menjadi 8,87 (TmtN5), 8,11 (TmtN2), dan 7,32 (GsgN2). Selanjutnya, pada akhir pengamatan di minggu ke-20, jumlah sel dalam Log CFU menjadi 6,07 (TmtN5), 5,56 (TmtN2), dan 6,11 (GsgN2). Jika dibandingkan jumlah sel bakteri antara minggu ke-20 dan minggu pertama pengamatan, maka terdapat penurunan sebesar 37,42\% (TmtN5), 41,78\% (TmtN2), dan 33,80\% (GsgN2). Data viabilitas sel konsorsium bakteri pada formula disajikan pada Gambar 1. 


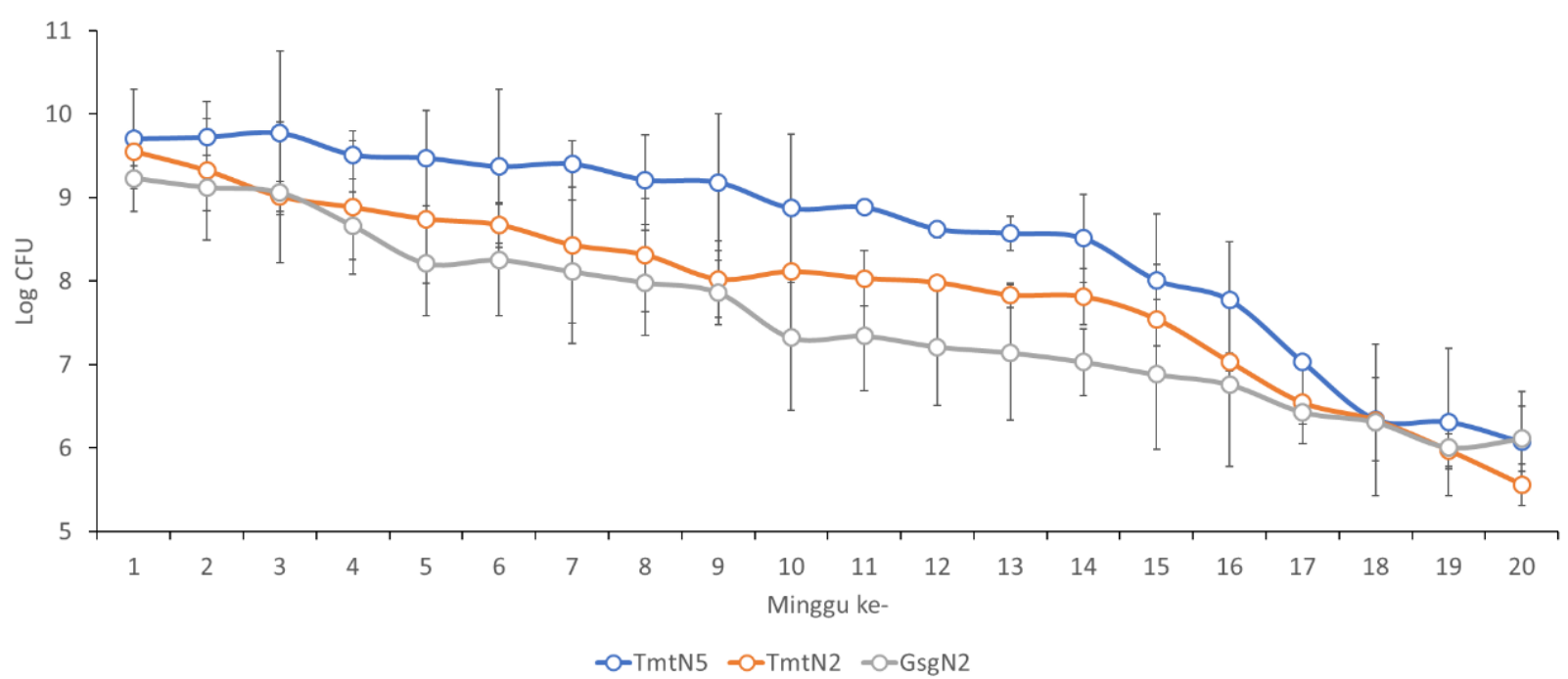

Gambar 1. Viabilitas konsorsium bakteri endofit di dalam formula selama 20 minggu

\section{Efektifitas Formula Konsorsium Bakteri Endofit Sebagai Agens Biokontrol M. incognita Pada Tomat}

Hasil penelitian menunjukkan formula konsorsium bakteri memberikan respon yang beragam pada peubah pengamatan yang diukur. Pada jumlah daun, seluruh formula konsorsium tidak memberikan hasil yang berbeda nyata dengan tanaman kontrol meskipun rata-rata jumlah daunnya lebih tinggi dibandingkan dengan rata-rata jumlah daun tanaman kontrol $(7,66)$. Selanjutnya, pada peubah pengamatan bobot segar tanaman, hanya TmtN2 yang memberikan hasil berbeda nyata dengan bobot segar tanaman kontrol. Jika dibandingkan dengan bobot segar tanaman kontrol (59,33 g), maka bobot segar tanaman dengan perlakuan formula konsorsium TmtN2 (84,95 g) lebih tinggi 43,18\%. Selanjutnya, pada peubah pengamatan panjang akar, aplikasi formula konsorsium bakteri endofit tidak memberikan pengaruh nyata terhadap panjang akar tanaman jika dibandingkan dengan panjang akar tanaman kontrol $(36,25$ $\mathrm{cm})$.

Hasil penelitian terhadap jumlah $M$. incognita di tanah memberikan hasil yang beragam. Formula konsorsium bakteri endofit TmtN5 dan TmtN2 memberikan hasil populasi $M$. incognita yang berbeda dengan tanaman kontrol. Formula konsorsium TmtN2 memberikan hasil terbaik dengan jumlah populasi $M$. incognita di tanah sebanyak 55,33; diikuti oleh formula konsorsium TmtN5 dengan populasi $M$. incognita sebanyak 73,50. Jika dibandingkan dengan populasi nematoda di tanah pada tanaman kontrol (137), maka formula konsrosium TmtN2 memberikan penekanan populasi sebesar $58,61 \%$, dan formula konsorsium TmtN5 memberikan penekanan populasi sebesar $46,35 \%$. Selanjutnya, pada peubah pengamatan populasi nematoda di dalam akar, seluruh perlakuan tidak memberikan pengaruh nyata. Meskipun secara jumlah lebih kecil dibandingkan dengan nematoda pada akar tanaman kontrol, namun pada uji selang berganda duncan dengan taraf kepercayaan 95\% tidak terdapat perbedaan nyata. Pada peubah pengamatan jumlah puru pada akar, hanya formula konsorsium TmtN5 yang memberikan hasil berbeda nyata dengan tanaman kontrol. Jumlah puru akar pada tanaman dengan perlakuan formula TmtN5 adalah 125,83. Jika dibandingkan dengan jumlah puru akar pada tanaman kontrol $(256,17)$, maka formula TmtN5 memberikan penekanan jumlah puru akar sebesar $50,88 \%$. Data pertumbuhan tanaman tomat terinfeksi $M$. incognita dengan perlakuan formula konsorsium bakteri endofit disajikan pada Tabel 2. 


\section{TECHNO: Vol. 09 (02) Oktober 2020}

Tabel 2. Pengaruh formula konsorsium bakteri terhadap pertumbuhan tanaman tomat terinfeksi M. incognita

\begin{tabular}{lllllll}
\hline $\begin{array}{l}\text { Kode } \\
\text { Formula }\end{array}$ & $\begin{array}{l}\text { Jumlah } \\
\text { Daun }\end{array}$ & $\begin{array}{l}\text { Bobot } \\
\text { Tanaman }(\mathrm{g})\end{array}$ & $\begin{array}{l}\text { Panjang } \\
\text { Akar }(\mathrm{cm})\end{array}$ & $\begin{array}{l}\text { Populasi NPA } \\
\text { di Tanah }\end{array}$ & $\begin{array}{l}\text { Populasi } \\
\text { NPA di Akar }\end{array}$ & $\begin{array}{l}\text { Jumlah } \\
\text { Puru Akar }\end{array}$ \\
\hline TmtN5 & $9,66 \mathrm{a}$ & $75,78 \mathrm{ab}$ & $39,66 \mathrm{a}$ & $73,50 \mathrm{~b}$ & $28,66 \mathrm{a}$ & $125,83 \mathrm{~b}$ \\
TmtN2 & $8,66 \mathrm{a}$ & $84,95 \mathrm{a}$ & $48,83 \mathrm{a}$ & $55,33 \mathrm{~b}$ & $32,83 \mathrm{a}$ & $148,17 \mathrm{ab}$ \\
GsgN2 & $9,44 \mathrm{a}$ & $67,31 \mathrm{~b}$ & $36,92 \mathrm{a}$ & $92,00 \mathrm{ab}$ & $36,12 \mathrm{a}$ & $162,33 \mathrm{ab}$ \\
Kontrol & $7,66 \mathrm{a}$ & $59,33 \mathrm{~b}$ & $36,25 \mathrm{a}$ & $137,00 \mathrm{a}$ & $37,50 \mathrm{a}$ & $256,17 \mathrm{a}$ \\
\hline
\end{tabular}

Angka-angka pada kolom yang diikuti oleh huruf yang sama tidak berbeda nyata pada p-value 0.05 (uji selang berganda Duncan).

\section{Pembahasan}

Bakteri endofit hidup di dalam jaringan tanaman dan memiliki interaksi erat dengan inangnya. Interaksi yang terjadi bersifat saling menguntungkan dimana bakteri endofit memperoleh nutrisi dan ruang untuk hidupnya, dan tanaman memperoleh keuntungan dari aktifitas fisiologi bakteri endofit (Brader et al., 2014; Chebotar et al., 2015). Beberapa hasil aktifitas fisiologi bakteri endofit disekresikan dalam bentuk metabolit sekunder yang dapat dimanfaatkan untuk menekan patogen tanaman secara langsung maupun tidak langsung (Ludwig-Müller, 2015). Aplikasi beberapa isolat bakteri endofit secara bersamaan dalam bentuk konsorsium dilaporkan lebih efektif dibandingkan dengan aplikasi bakteri endofit secara tunggal. Hal ini disebabkan aktifitas fisiologi bakteri endofit dalam bentuk konsorsium lebih tinggi, dan metabolit sekunder yang dihasilkannya lebih beragam (Mukherjee et al., 2018).

Efektifitas konsorium bakteri endofit dalam menekan populasi nematoda parasit tanaman telah dilaporkan sebelumnya. Munif dan Giyanto (2015) melaporkan konsorsium bakteri endofit efektif menekan populasi Pratylenchus coffeae pada tanaman kopi di rumah kaca. Selanjutnya, pada laporan terpisah, Munif et al. (2019) juga melaporkan konsorsium bakteri endofit efektif dalam menekan populasi nematoda Meloidogyne spp. Kemampuan konsorsium bakteri endofit dalam menekan populasi nematoda dan keparahan kerusakan akar akibat infeksi nematoda didukung oleh kemampuannya dalam menghasilkan beberapa enzim ekstraseluler (Singh et al., 2017).

Enzim ektraseluler yang dihasilkan oleh bakteri endofit yang berkaitan dengan kemampuannya sebagai anti-nematoda adalah enzim protease, dan enzim kitinase. Enzim protease berperan dalam mendegradasi struktur protein yang merupakan salah satu penyusun penting dinding sel nematoda (Siddiqui et al., 2005; Qiuhong et al., 2006). Sejalan dengan enzim protease, enzim kitinase juga bersifat nematisidal karena sifatnya yang dapat mendegradasi kitin yang juga merupakan salah satu komponen utama dinding sel nematoda (Mercer et al., 1992). Menurut Miller dan Sands (1977) enzim protease dan kitinase dapat menekan persentase penetasan telur M. incognita. Selanjutnya, Safni et al. (2018) melaporkan bahwa bakteri endofit mampu menghancurkan struktur stilet nematoda Meloidogyne spp. Hancurnya stilet pada nematoda diduga berkaitan dengan aktifitas bakteri endofit yang mampu memproduksi enzim protease dan kitinase. Selain mampu menghasilkan enzim ektraseluler, kemampuan bakteri endofit dalam mengendalikan nematoda parasit tanaman juga berkaitan dengan kemampuannya dalam menghasilkan senyawa volatil $\mathrm{HCN}$. $\mathrm{HCN}$ dikenal bersifat toksik bagi nematoda, namun pada konsentrasi rendah tidak berbahaya bagi tanaman (Yousif et al., 2017). 
Secara tidak langsung, bakteri endofit dapat meningkatkan ketahanan tanaman terhadap nematoda melalui mekanisme induksi resistensi. Tanaman yang diberi perlakuan bakteri endofit memproduksi metabolit PR-Protein dan senyawa pertahanan seperti senyawa tanin, fenol, dan glikosida yang lebih tinggi (Bora et al., 2019). Selain itu, kemampuan konsorsium bakteri endofit dalam memfiksasi $\mathrm{N}$ dari lingkungan dan melarutkan $\mathrm{P}$ yang terikat di tanah juga secara tidak langsung dapat meningkatkan ketahanan tanaman (Dias et al., 2009). Keseimbangan nutrisi yang diserap oleh tanaman dilaporkan menjadi salah satu faktor kunci pertahanan tanaman dari serangan dan infeksi OPT.

Kemampuan formula konsorsium bakteri endofit dalam mengendalikan nematoda sangat dipengaruhi oleh jenis bahan pembawa yang digunakan. Bahan pembawa menentukan viabilitas, dan jumlah sel yang bertahan selama proses penyimpanan. Semakin melimpah jumlah sel agens hayati yang diaplikasikan pada suatu tanaman, maka kemungkinan keberhasilan pengendalian hayati akan semakin tinggi (Ojiambo dan Scherm, 2006; Raymaekers et al., 2020). Kelengkapan nutrisi menjadi kunci keberhasilan sebuah formula dalam mengendalikan patogen tanaman. Pada penelitian terpisah, Munif dan Mutaqin (2016) berhasil menekan keparahan penyakit akibat infeksi nematoda puru akar menggunakan formula bakteri endofit dalam bentuk tepung. Selanjutnya, Brand et al. (2004) juga melaporkan berhasil membuat formula bakteri endofit dalam bentuk padat yang efektif menekan kejadian penyakit akibat infeksi Meloidogyne spp.

\section{KESIMPULAN}

Penelitian ini memberikan informasi terdapat 3 konsorsium bakteri endofit $\left(\mathrm{TmtN}_{5}, \mathrm{TmtN}\right.$, dan $\mathrm{GsgN}_{2}$ ) yang berpotensi menjadi agens pengendali hayati nematoda puru akar, dan ketiganya memiliki jumlah sel yang relatif stabil pada formula padat, serta efektif menekan infeksi Meloidogyne incognita dan memacu pertumbuhan tomat terinfeksi nematoda puru akar.

\section{REFERENCES}

Anjum, R., Afzal, M., Baber, R., Khan, M.A.J., Kanwal, W., Sajid, W., dan Raheel, A. 2019. Endophytes: as potential biocontrol agent-review and future prospects. Journal of Agricutural Science. 11: 113-125. doi: 10.5539/jas.v11n4p113.

Ashraf, S., Afzal, M., Naveed, M., Shahid, M., dan Ahmad, Z. 2018. Endophytic bacteria enhance remediation of tannery effluent in constructed wetlands vegetated with Leptochloa fusca. International Journal of Phytoremediation. 20(2): 121-128. doi: 10.1080/15226514.2017.1337072.

Basheer, J., Ravi, A., Mathew, J., dan Krishnankutty, R.E. 2019. Assessment of plant-probiotic performance of novel endophytic Bacillus sp. in talc-based formulation. Probiotics and Antimicrobial Proteins. 11(1): 256-263. doi: 10.1007/s12602-018-9386-y.

Bora, P., Saikia, K., Hazarkia, H., dan Ragesh, G. 2019. Exploring potential of bacterial endophytes in disease management of horticultural crops. Current Horticulture. 7(2): 32-37. doi: 10.5958/24557560.2019.00016.5.

Brader, G., Compant, S., Mitter, B., Trognitz, F., dan Sessitsch, A. 2014. Metabolic potential of endophytic bacteria. Current Opinion in Biotechnology. 27: 30-37. doi: 10.1016/j.copbio.2013.09.012.

Brand, D., Roussos, S., Pandey, A., Zilioli, P.C., Pohl, J., dan Soccol, C.R. 2004. Development of a bionematicide with Paecilomyces lilacinus to control Meloidogyne incognita. Applied Biochemistry and Biotechnology. 118(1-3): 81-88. doi: 10.1385/ ABAB:118:1-3:081. 


\section{TECHNO: Vol. 09 (02) Oktober 2020}

Cetintas, R., Kusek, M., dan Fateh, S.A. 2018. Effect of some plant growth-promoting rhizobacteria strains on root-knot nematode, Meloidogyne incognita, on tomatoes. Egyptian Journal of Biological Pest Control. 28(1): 1-5. doi: 10.1186/s41938-017-0008-x.

Chawla, G., Singh, K.P., dan Srivastava, A. 2006. Study on propagation of root knot nematode, Meloidogyne incognita (Kof oid \& White) Chitwood, through tuberose (Polianthes tuberosa Linn.) bulbs. Journal of Ornamental Horticulture. 9(1): 73-74.

Chebotar, V., Malfanova, N., Shcherbakov, A., Ahtemova, G., Borisov, A.Y., Lugtenberg, B., dan Tikhonovich, I. 2015. Endophytic bacteria in microbial preparations that improve plant development. Applied Biochemistry and Microbiology. 51(3): 271-277. doi: 10.1134/S0003683815030059.

Dias, A.C., Costa, F.E., Andreote, F.D., Lacava, P.T., Teixeira, M.A., Assumpçao, L.C., Araújo, W.L., Azevedo, J.L., dan Melo, I.S. 2009. Isolation of micropropagated strawberry endophytic bacteria and assessment of their potential for plant growth promotion. World Journal of Microbiology and Biotechnology. 25(2): 189-195. doi: 10.1007/s11274-008-9878-0.

Eljounaidi, K., Lee, S.K., dan Bae, H. 2016. Bacterial endophytes as potential biocontrol agents of vascular wilt diseases-review and future prospects. Biological Control. 103: 62-68. doi: 10.1016/j.biocontrol.2016.07.013.

Furusawa, A., Uehara, T., Ikeda, K., Sakai, H., Tateishi, Y., Sakai, M., dan Nakaho, K. 2019. Ralstonia solanacearum colonization of tomato roots infected by Meloidogyne incognita. Journal of Phytopathology. 167(6): 338-343. doi: 10.1111/jph.12804.

Hu, H.J., Chen, Y.L, Wang, Y.F., Tang, Y.Y., Chen, S.L., dan Yan, S.Z. 2017. Endophytic Bacillus cereus effectively controls Meloidogyne incognita on tomato plants through rapid rhizosphere occupation and repellent action. Plant Disease. 101(3): 448-455. doi: 10.1094/PDIS-06-16-0871-RE.

Khanna, K., Jamwal, V.L., Kohli, S.K., Gandhi, S.G., Ohri, P., Bhardwaj, R., Wijaya, L., Alyemeni, M.N., dan Ahmad, P. 2019. Role of plant growth promoting Bacteria (PGPRs) as biocontrol agents of Meloidogyne incognita through improved plant defense of Lycopersicon esculentum. Plant and Soil. 436(1-2): 325-345. doi: 10.1007/s11104-019-03932-2.

Kumar, N., Bhatt, J., dan Sharma, R.L. 2017. Interaction between Meloidogyne incognita with Fusarium oxysporum f. sp. lycpersici on Tomato. International Journal of Current Microbiology and Applied Sciences. 6: 1770-1776. doi: 10.20546/ijcmas.2017.608.209.

Ludwig-Müller, J. 2015. Plants and endophytes: equal partners in secondary metabolite production? Biotechnology Letters. 37(7): 1325-1334. doi: 10.1007/s10529-015-1814-4.

Mercer, C., Greenwood, D., dan Grant, J. 1992. Effect of plant and microbial chitinases on the eggs and juveniles of Meloidogyne hapla Chitwood (Nematoda: Tylenchida). Nematologica. 38(1-4): 227-236. doi: $10.1163 / 187529292 X 00199$.

Miller, P., dan Sands, D. 1977. Effects of hydroclytic enzymes on plant-parasitic nematodes. Journal of Nematology. 9(3): 192-197.

Muhae-ud-Din, G., Moosa, A., Ghummen, U.F., Jabran, M., Abbas, A., Naveed, M., Jabbar, A., dan Ali, M.A. 2018. Host status of commonly planted ornamentals to Meloidogyne incognita and management through endophytic bacteria. Pakistan Journal of Zoology. 50(4): 1393-1402. doi: 10.17582/journal.pjz/2018.50.4.1393.1402.

Mukherjee, G., Saha, C., Naskar, N., Mukherjee, A., Mukherjee, A., Lahiri, S., Majumder, A.L., dan Seal, A. 2018. An endophytic bacterial consortium modulates multiple strategies to improve arsenic phytoremediation efficacy in Solanum nigrum. Scientific Reports. 8(1): 1-16. doi: 10.1038/s41598-01825306-x.

Munif, A., dan Giyanto, G. 2015. Effectiveness of endophytic bacterial consortium of coffee plant on mortality of Pratylenchus coffeae in vitro. Pelita Perkebunan. 31(3): 175-185.

Munif, A., Hallmann, J., dan Sikora, R.A. 2013. The influence of endophytic bacteria on Meloidogyne incognita infection and tomato plant growth. ISSAAS. 19(2): 68-74.

Munif, A., Herliyana, E.N., dan Pradana, A.P. 2019. Endophytic bacterial consortium originated from forestry plant roots and their nematicidal activity against Meloidogyne incognita infestation in greenhouse. Acta Universitatis Agriculturae et Silviculturae Mendelianae Brunensis. 67(5): 1171-1182. doi: 10.11118/actaun201967051171. 


\section{Pradana, A.P., A. Munif, Supramana. 2020. biocontrol; compost; formula; suppression; viability}

Munif, A., Mutaqin, K.H. 2016. Lama penyimpanan, karakterisasi fisiologi, dan viabilitas bakteri endofit Bacillus sp. dalam formula tepung. Jurnal Fitopatologi Indonesia. 12(1): 19-26. doi: 10.14692/jfi.12.1.19.

Ntalli, N., dan Caboni, P. 2017. A review of isothiocyanates biofumigation activity on plant parasitic nematodes. Phytochemistry Reviews. 16(5): 827-834. doi: 10.1007/s11101-017-9491-7.

Ojiambo, P., dan Scherm, H. 2006. Biological and application-oriented factors influencing plant disease suppression by biological control: a meta-analytical review. Phytopathology. 96(11): 1168-1174. doi: 10.1094/PHYTO-96-1168.

Pradana, A, P., Munif, A., dan Supramana, S. 2016. Bakteri endofit asal berbagai akar tanaman sebagai agens pengendali nematoda puru akar Meloidogyne incognita pada tomat. Jurnal Fitopatologi Indonesia. 12(3): 75-75. doi: 10.14692/jfi.12.3.75.

Qiuhong, N., Xiaowei, H., Baoyu, T., Jinkui, Y., Jiang, L., Lin, Z., dan Keqin, Z. 2006. Bacillus sp. B16 kills nematodes with a serine protease identified as a pathogenic factor. Applied Microbiology and Biotechnology. 69(6): 722-730. doi: 10.1007/s00253-005-0019-5.

Raymaekers, K., Ponet, L., Holtappels, D., Berckmans, B., dan Cammue, B.P. 2020. Screening for novel biocontrol agents applicable in plant disease management-a review. Biological Control. 144: 1-18. doi: 10.1016/j.biocontrol.2020.104240.

Safni, I., Lubis, K., Tantawi, A.R., dan Murthi, S. 2018. Isolation and characterization of rhizobacteria for biological control of root-knot nematodes in indonesia. Journal of the International Society for Southeast Asian Agricultural Sciences. 24(1): 67-81.

Siddiqui, I.A., Haas, D., dan Heeb, S. 2005. Extracellular protease of Pseudomonas fluorescens CHA0, a biocontrol factor with activity against the root-knot nematode Meloidogyne incognita. Applied and Environmental Microbiology. 71(9): 5646-5649. doi: 10.1128/AEM.71.9.5646-5649.2005.

Singh, M., Kumar, A., Singh, R., dan Pandey, K.D. 2017. Endophytic bacteria: a new source of bioactive compounds. 3 Biotech. 7(5): 315-321. doi: 10.1007/s13205-017-0942-z.

Varkey, S., Anith, K., Narayana, R., dan Aswini, S. 2018. A consortium of rhizobacteria and fungal endophyte suppress the root-knot nematode parasite in tomato. Rhizosphere. 5: 38-42. doi: 10.1016/j.rhisph.2017.11.005. .

Viljoen, J.J., Labuschagne, N., Fourie, H., dan Sikora, R.A. 2019. Biological control of the root-knot nematode Meloidogyne incognita on tomatoes and carrots by plant growth-promoting rhizobacteria. Tropical Plant Pathology. 44(3): 284-291. doi: 10.1007/s40858-019-00283-2.

Xiang, N., Lawrence, K.S., Kloepper, J.W., Donald, P.A., McInroy, J.A., dan Lawrence, G.W. 2017. Biological control of Meloidogyne incognita by spore-forming plant growth-promoting rhizobacteria on cotton. Plant Disease. 101(5): 774-784. doi: 10.1094/PDIS-09-16-1369-RE.

Yousif, A.I., Munif, A., dan Mutaqin, K.H. 2017. Evaluating the toxicity of secondary me tabolites of endophytic bacteria from Jatropha curcas L. to suppress Meloidogyne spp. in vitro. International Journal of Science and Research. 6: 2195-2199. doi: 10.21275/ART20172700. 